\title{
The risk of relationship between hormonal replacement therapy and cancer
}

\author{
Thiele Osvaldt Rosales ${ }^{1}$, Iara Patrícia Albrecht ${ }^{1}$, Guilherme Barroso Langoni de Freitas ${ }^{1,2, ~ * ~}$ \\ ${ }^{1}$ Department of Pharmacy, State University of Center-West, Guarapuava, Parana, Brazil \\ ${ }^{2}$ Post-Degree Program in Internal Medicine and Health Sciences at UFPR, Department of Clinical Patology, Federal University of Parana, \\ Curitiba, Parana, Brazil
}

Email address:

thi_rosales@hotmail.com (T. O. Rosales), iara-nk@hotmail.com (I. P. Albrecht), prof.gbarroso@yahoo.com.br (G. B. L. de Freitas)

\section{To cite this article:}

Thiele Osvaldt Rosales, Iara Patrícia Albrecht, Guilherme Barroso Langoni de Freitas. The Risk of Relationship between Hormonal Replacement Therapy and Cancer. Cancer Research Journal. Special Issue: Lifestyle and Cancer Risk. Vol. 2, No. 6-1, 2014, pp. 49-56. doi: 10.11648/j.crj.s.2014020601.16

\begin{abstract}
Menopause is an endocrine condition due to the decline in ovarian activity, which occurs in all women and is characterized as a progressive hypoestrogenism. To minimize damage from lack hormonal activity, hormone replacement therapy has been developed (TRH), which is widely used around the world, often without criteria pre-established. Thus, this study aims to identify hormonal therapies used postmenopausal and relate them to the development of tumors. In addition, identify the criteria for the use of HRT, the utilization time and women who are part of the risk groups are also objectives of this study. In the beginning, the clinical methodology of HRT included only estrogen, but epidemiological studies have observed that the progestin presence is essential in endometrial hyperplasia control adding to the therapy. Progestogens act depending on its molecular structure, and consequently selectivity, or may interact with other steroid receptors. From this interaction, different pharmacodynamic answers about importance in the development of tumors can be observed, ie, progesterone activity, estrogen, antiestrogen, androgen and / or antiandrogen. In view of the mechanism of carcinogen administration of estrogens, it can be said that HRT increases the risk of breast, uterus and ovary cancer. However, the estrogenic actions may be adjusted when there is administration of progestin drugs and with antiestrogenic and antiandrogenic actions. Given this, in menopausal women, it is advisable to trace gynecological cancer, before, during and after any therapeutic interventions, and the decision of using and the choice of HRT on an individual basis, through a careful assessment of signs and symptoms and long-term risk.
\end{abstract}

Keywords: Hormonal replacement therapy, Cancer, Estrogens, Progestogen

\section{Introduction}

Menopause is an endocrine condition due to the decline in ovarian activity, which occurs in all women and is characterized as a progressive hypoestrogenism. Thus, the menopause is the point at which menstruation ceases permanently as a result of loss of ovarian follicular activity. As the ovarian follicles produce estrogen and progesterone, hormones with autocrine and paracrine activity, menopause causes several physiological changes because of the decrease of these hormones [1,2].

Estrogen deficiency implies to vasomotor symptoms [3], urogenital atrophy [4], cognitive decline [5], as well as increased risk of chronicity-co-degenerative diseases such as atherosclerosis [6], cardiovascular disease [7], osteoporosis [8] and Alzheimer's disease [5]. Progesterone, in turn, acts by modulating estrogen-gene effects [4], acting in many cases even in control and reducing the risk of estrogen-dependent cancers, eg breast [9], uterus [10] and ovarian [11].

In order to minimize this damage caused by the absence of hormonal activity, hormone reposition therapy (HRT) was developed, which is widely used around the world, often without pre-established criteria [12].

Until the 80s, HRT was made using only estrogen, thereby reducing, vasomotor symptoms, vaginitis and osteoporosis [13]. However, studies indicate that this treatment was associated with a significant increased incidence of endometrial carcinoma [14, 15, 16], related by continuous stimulation of endometrial hyperplasia by estrogens acting unopposed of progestin. From that point, the preparations used in HRT contain a combination of estrogen and progesterone [12]. However, HRT in some women may generate more harmful effects than good ones. This will depend on the 
presence of risk factors, hormones used, the utilization time and real necessity of implementing of this treatment.

Thus, this study aims to identify hormonal therapies used postmenopausal and relate them to the development of tumors. In addition, identify the criteria for utilization of HRT, the utilization time and women who are part of the risk groups are also objectives of this study.

\section{Drugs and HRT}

Currently, the therapeutic regimens in HRT can be administered in a cyclic or continuous manner, including the joint use of hormones (combined) or the administration of estrogens and progestin isolated. Initially, the HRT of clinical methodology included only estrogen [13], but some epidemiological studies found progestagen presence is essential in endometrial hyperplasia control, adding to the therapy [14-16]. In continuous HRT, hormone administration takes place without interruption and can be performed in a simple way (when used estrogens or progestins alone) or in combination (estrogens and progestins associated). In the cyclic or sequential regimen, estrogen is administered continuously and the progestin is added for ten to fourteen days of the cycle each month $[17,18]$. The main associations found in HRT are listed in Table $1[19,20]$.

The main endogenous estrogens are $17 \beta$-estradiol, estrone and estriol. The phenolic ring attached to a hydroxyl radical present in these hormones is the main structural feature responsible for the selective binding and high affinity to estrogen receptors. In the body, the highest affinity is observed for $17 \beta$-estradiol, followed by estriol and estrone [21]. The synthetic estrogens are mestranol, ethinylestradiol, quimestrol and diethylstilbestrol [13]. Ethinylestradiol is the most common synthetic estrogen in HRT, and the higher potency because it has high small intestinal absorption and first pass metabolism in the liver [12].

In women of reproductive age, the ovaries are the main source of circulating estrogens, favoring the production of estradiol and testosterone from the estrone and androstenedione, respectively. In the liver, estradiol is converted into estrone and then to estriol. In postmenopausal women, the main source of estrogen is estrone, synthesized from dehydroepiandrosterone (DHEA) in adipose tissue [21].

For the progestogen, the natural hormone is progesterone and the amount of synthetic derivatives far exceeds estrogens, both in quantity, but mainly in the diversity of biological effects. Examples of derivatives are cyproterone acetate, medroxyprogesterone acetate, nomegestrol acetate, diidroxiprogesterona, norgestrel, trimegestone and others, as well as derivatives of testosterone such as norgestimate, desogestrel and levonorgestrel and also drospirenone having similar structure to spironolactone [22]. All chemicals that mimic the action of progesterone are called progestins or progestogens and their biological properties depend on their molecular structure and consequent selectivity [23, 24].

Table 1. Main associations (estrogen and progestogen) found in HRT

\begin{tabular}{|c|c|c|}
\hline Commercial Name & Estrogen & Progestogen \\
\hline Activella ( & Estradiol & Norethindrone acetate \\
\hline Angeliq ${ }^{\circledR}$ & Estradiol & Drospirenone \\
\hline 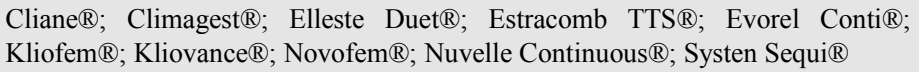 & Estradiol & Norethindrone acetate \\
\hline Climene ${ }^{\circledR}$ & Estradiol & Cyproterone acetate \\
\hline Climesse $\AA$; Clinorette $\AA$; Trisequens $\AA$ & Estradiol & Norethisterone \\
\hline Dilena ${ }^{\circledR}$; Indivina ${ }^{\circledR}$; Tridestra ${ }^{\circledR}$ & Estradiol & Acetato de Medroxiprogesterona \\
\hline Femoston $®$ & Estradiol & Diidrogesterone \\
\hline FemSeven Conti ${ }^{\circledR}$ & Estradiol & Levonorgestrel \\
\hline Jinteli ${ }^{\circledR}$; Mimvey ${ }^{\circledR}$ & Ethinylestradiol & Norethindrone acetate \\
\hline Lindisc Duo ${ }^{\circledR}$; Progynova ${ }^{\circledR}$ & Estradiol & Norgestrel \\
\hline Prefest ${ }^{\circledR}$ & Estradiol & Norgestimate \\
\hline 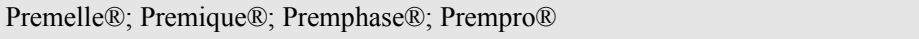 & Conjugated estro. & Medroxyprogesterone acetate \\
\hline Prempak-C® & Conjugated estro. & Norgestrel \\
\hline
\end{tabular}

That is, progestins can interact with other steroid receptors, e.g., androgenic, estrogenic and even mineralocorticoids and glucocorticoids [22]. From this interaction, different pharmacodynamic answers and the importance in the development of tumors can be observed, ie progesterone activity, estrogen, antiestrogen, androgen and / or antiandrogen. Progestogens drugs used in HRT with their respective shares are listed in Table 2.

The progesterone actions are mediated by the progesterone receptor (PR, or also known as NR3C3 nuclear receptor subfamily 3). Have been identified in humans two isoforms for this receptor, $\mathrm{PR}-\mathrm{A}$ and $\mathrm{CP}-\mathrm{B}$, which are derived from a single gene and control transcriptional factors [26, 27]. PR-A acts as an inhibitor of transcription of other steroid receptors such as estrogen and androgen, and PR-B mediates the stimulatory activity of progesterone [27]. Thus, the progestin activity promotes cell differentiation and is capable of modulating the estrogenic effect (remarkable effects of cell proliferation).

Estrogens exert their physiological effects by interacting with nuclear receptors, which can be of two types, ER $\alpha$ and $\mathrm{ER} \beta$. The $\mathrm{ER} \alpha$ is present in more abundant amounts in the female reproductive tract, mainly the uterus, vagina and ovary, as well as in the mammary gland, the hypothalamus, endothelial cells and vascular smooth muscle. ER $\beta$, has higher expression in the ovary and lower in the lung, brain and 
vascular system $[28,29]$. The activation of nuclear receptors is followed by conformational changes in its structure to allow specific DNA sequences, called the steroid responsive elements (ERE), to bind to them. Transcription of early regulatory genes is induced upon binding of the complex to hormone receptor ERE. Early gene regulatory transcribe mRNA for proteins that enter the cell nucleus and regulate transcription of the late genes, which in turn encode mRNA for proteins, in other words, estrogen receptors activate transcription factors in the DNA responsible for regulating cell proliferation and homeostasis [30]. Therefore, substances with estrogenic activity induce cell proliferation and hyperplasia, increased risk of cancer and increasing aggressiveness of possible tumors. . Thus, the progestins acting on estrogen receptors, such as tibolone and norethindrone acetate mimic this effect. As for the antiestrogen action with progestins are capable of reducing the effects of estrogens and minimize the risk of neoplastic and other estrogenic effects HRT.

Table 2. Shares of the major progestins used in HRT.

\begin{tabular}{llllll}
\hline Progestin / Action & P & E & AE & A & AA \\
\hline Cyproterone acetate & + & - & + & - & ++ \\
Medroxyprogesterone acetate & + & - & + & \pm & - \\
Nomegestrol acetate & + & - & + & - & \pm \\
Norethindrone acetate & + & + & - & + & - \\
Desogestrel & + & - & - & + & - \\
Diidrogesterone & + & - & + & - & \pm \\
Drospirenone & + & - & + & - & + \\
Levonorgestrel & + & - & + & + & - \\
Norgestimate & + & - & + & + & - \\
Norgestrel & + & - & + & + & - \\
Progesterone & + & - & + & - & \pm \\
Tibolone & + & + & - & + & - \\
Trimegestone & + & - & - & - & - \\
\hline
\end{tabular}

P (pregestogenic); E (estrogenic); AE (antiestrogen); A (androgen); AA (antiandrogen); ++ (Very strong); + (Strong); \pm (slight); - (Poor). Adapted from $[22,25]$

The androgenic hormones, especially testosterone, are indicated in menopause in order to increase libido and sexual pleasure [31]. Effects such as increased bone density and muscle mass are also highlighted, making it useful in skeletal muscle strengthening as necessary for a healthy aging [32]. However, excessive testosterone in women can lead to the appearance of acne, hirsutism, aggression, water retention, increased blood pressure, fibrinogen, visceral fat and free fatty acids and insulin resistance as well as reduced HDL [33]. In this case the action of insulin resistance reduces glucose uptake in skeletal muscle, liver and adipose tissue. As a result, the pancreas starts to produce and release more insulin to maintain normal glucose levels, thereby increasing circulating insulin levels in a compensatory hyperinsulinemia mechanism [34]. Insulin has mitogenic action and the state of hyperinsulinemia is associated with increased risk of cancer, including breast, prostate and colon cancer $[35,36]$.

The hormones with androgenic characteristics are converted to estrogens by the action of the aromatase enzyme complex. At menopause, these enzymes are found mainly in adipose tissue and liver, and use as intermediates the testosterone or androstenedione in the conversion of oestradiol [28]. It is observed that aromatase activity is increased in obesity management and, as a result, there is an increase in estradiol formation and increased risk of tumors [37]. It is known that testosterone may influence the risk for breast cancer directly, or indirectly (in the conversion to estradiol). Androgen receptors have been identified in breast cancer cells and were revealed the association of free testosterone levels with breast cancer, regardless of bioavailable estradiol concentration $[38,39]$.

However the anti-androgenic activity is observed both estrogens as progestins, because there is inhibition of gonadotropin secretion in the activation of ER receptors and competition for androgen receptors through progestins [29]. Thus, progestogens with antiandrogenic action decrease the effects of androgen hormones.

HRT may be administered orally, parenterally, transdermally or topically in accordance with the structure of each drug [28]. Administration of progestin and estradiol by transdermal route, topically or parenterally, prevents the enterohepatic metabolism, causing less potential for stimulation of hepatic proteins on lipoprotein profiles, triglycerides and coagulation factors, with the most favorable risk cardiovascular disease and thromboembolism. That is, in the oral estrogen therapy, pass through the liver induces increased synthesis of various proteins such as clotting factors, carrier and genotypic sex steroid binding globulin (SHBG), which may cause hypercoagulability, increased blood pressure, decreased free fraction of circulating estrogens, respectively $[13,40]$.

Oral treatment of HRT has favorable effects on lipid metabolism by hepatic lipase enzyme blockade. Estrogens slightly elevate serum triglyceride levels and decrease total cholesterol. Also, there is an increase in HDL and a decrease in LDL [41].

The combined administration of estrogens and progestins, orally, demonstrated increased plasma insulin levels showing the harmful action of therapy in insulin action. transdermal hormone treatment had little effect on insulin metabolism [42]. The transdermal administration of estradiol lead to the slow and continuous release of the hormone, systemic distribution and more stable blood levels than the oral dosage form [21].

The creams containing estradiol conjugated estrogens present local effectiveness and may have systemic effects due to significant absorption of these hormones. Further, the estradiol may be administered by slow release through vaginal rings for use three months or vaginal tablets. Injectable drugs (intramuscularly) show prolonged action for oily preparations, in other words, estradiol esters becomes less polar as the size increases the absorption of substituents and is progressively reduced. A single intramuscular injection of compounds, such as estradiol valerate or estradiol cypionate in oil, can be absorbed per weeks [21].

The continuous regimen with oral conjugated estrogens increased serum SHBG after one year of treatment, while transdermal therapy did not affect the concentration. Still, free testosterone levels were not affected during the oral and 
transdermal treatments [43]. Thus, it was observed that oral treatment can balance increased stimulation of estrogen in tissues by increasing SHBG.

\section{Molecular Mechanism of HRT Carcinogen}

Although homeostatic functions, hormones are among the most important factors that induce or modulators of tumor cells [44]. It is believed that hormonal carcinogenesis different from those induced by viruses or chemical agents, cell proliferation does not require a specific initiator. In this case, are the hormones that induce cell proliferation, resulting as a consequence of genetic mutations that give rise to neoplastic cells [45].

Among the hormone dependent cancers stand out breast cancer, uterus (endometrium and smooth muscle) and ovary [46], but other types are also being related to the action of hormones such as testis, prostate, thyroid and osteosarcoma [47]. The use of HRT may also increase the risk of relative meningioma [48].

Breast cancer is the second most common in the world and the most common among women. In 2014, were estimated 57.12 million new cases of breast cancer. However, for cervical cancer were 15 million new cases and 5.68 million for ovarian cancer $[49,50]$.

In hyperplastic and neoplastic processes, normal growth control mechanism is changed as a result of changes in cell proliferation mediators expression (TGF $\alpha$, VEGF, PDGF, IGF-1 and IRS) and activation proto oncogeneses (c-met proto-, myc, HER-2, etc.) [51].

When neoplastic reach proto oncogenes, which are at first inactive in normal cells are transformed into oncogenes, genes with potential to transform normal cells into neoplastic, through protein coding. These cells then are called tumor [52]. Tumor cells now begin to multiply out of control, requiring for it, new blood vessels for nutrition, in a process called angiogenesis [53]. The estrogen receptor, when activated, catalyzes the expression of MAPK proteins (protein kinase activator mitosis) determining the inhibition of apoptosis. Receptor activation also results in increased expression of EGFR (epidermal growth factor receptor) and synthesis of mRNA, facilitating a higher rate of tumor growth [54]. Estrogens also activate VEGF-A (vascular endothelial growth factor) which is related to the process of angiogenesis and closely related with proliferative processes [55].

The mass accumulation and cells form malignant tumors, which have characteristics of invasiveness and metastasis. Thus, migration and invasion of other tissues becomes a matter of time, which depends on the location, the body's defenses, endogenous and exogenous factors pro- and anti-tumor and tumor type. If reach blood vessels or lymphatic system, increase the chance to migrate to other organs distant from the tumor origin site, forming metastases and worsening of the patient's recovery perspective. And as the cancer cells will replace normal cells, injured tissues lose their functions [53].

\subsection{Endometrial Cancer}

Endometrial cancer is the sixth most common type among women, with approximately 319000 new cases in the word [56]. The incidence occurs in $80 \%$ of cases, perimenopausal and postmenopausal, with women over 60 years, a risk four times greater than from 20 to 60 years. It's a rare incidence in women younger than 50 years [57].

The relationship of endometrial cancer with estrogen replacement therapy (ERT) has been observed in studies in the 1970s. Experimental and epidemiological evidence showed that the increase in the incidence of cancer was directly related to the dosage-time dependent use of estrogens. Progesterone was then added in therapy after having a protective effect [58-60].

Continuous stimulation of endometrial hyperplasia by the action of estrogens without opposition by progesterone leads to the development of endometrial cancer. The effects of progesterone in endometrial cell proliferation stimulated by estrogen action were observed in reducing the amount of estrogen receptors, increased local conversion of estradiol to estrone and less potent in the endometrial conversion of proliferative action of the secretory state [10, 13, 28]. The isolated treatment with ERT increases the risk of endometriosis and determines the risk two to three times of endometrial cancer in women with a uterus compared to non-users of therapy $[61,62]$. However, progestin association in 12 day cycles, or at least continuously demonstrated a protective effect on the endometrium, determining similar risk between users and non-users of HRT [63].

In patients who underwent hysterectomy, endometrial carcinoma is no longer worrying and estrogen is usually more used alone [64]. However, it is noteworthy that other dependent hormones cancer, such as breast cancer also is at risk in HRT.

The dose and duration of estrogen therapy are the biggest risk factors for the development of endometrial cancer. The longer the duration of therapy, the greater the relative risk of endometrial cancer [10]. With the use of HRT for more than 10 years, the risk is eight to ten times greater, 46 representing the most cases of endometrial cancer in women 100,000 / year [65].

In addition, factors such as metabolic syndrome, obesity, insulin resistance and Type II diabetes, also promote endometrial stimulation and increase the risk of cancer [66].

\subsection{Breast Cancer}

Breast cancer is the second most common type in the world, is the most common among women, accounting for $22 \%$ of new cases each year and an estimated 57,120,000 new cases in the world for the year 2014. For rare before 35, above this age its incidence is growing rapidly and progressively [67].

There is still controversy regarding the risk of breast cancer due to HRT. Some studies suggest that there is no increase in the risk of this cancer, but others demonstrated a significant increase related to duration of therapy $[68,69]$. Is known that estrogen acts by promoting cell growth by stimulating the release of tumor growth factor alpha (TNF-alpha), and growth 
factor similar to insulin and inhibit the tumor growth factor $\beta$ [70].

Women with natural or surgical menopause and no history of breast cancer after 5 years using estrogen with or without progestin, had no increased risk of disease [71]. However, after 15 years of use, there was an increase of $30 \%$ in the group that made use of the TER [71]. Patients who had a family history of breast cancer and estrogen users had double the risk. However, other risk factors were not assessed as obesity, genetic alterations and doses.

Another study found that each year of HRT use, the relative risk of breast cancer is $2.3 \%$, and the use of up to five years did not significantly alter the risk. In women not using HRT, between 50 and 70 years for every 1,000 women are expected 45 new cases of breast cancer [72].

The development of breast cancer is essentially determined by the intensity and duration of exposure of the breast epithelium to the joint action of prolactin and estrogen. However, the possibility of prolactin stimulate mitotic activity of mammary epithelial cells cannot be ignored [46].

In the assessment of the effects mediated by progesterone in breast tissue, there was a heightened state of cell differentiation associated with a lower ability to metastasis, thus highlighting its importance in HRT [73].

Another recommended treatment for postmenopausal women with estrogen deprivation would be through the use of adjuvant endocrine therapy as an aromatase inhibitor (AI). This works by inhibiting estrogen synthesis, and thereby preventing the aromatase enzyme in androgen conversion to estrogen [74]. However, the adverse effects of this therapy may affect sexual functioning, due to the suppression of estradiol effects [75, 76]. Among the reported effects are vaginal dryness, decreased sex drive, dissatisfaction with their sex life and sexual dysfunction [77]. One way to address these effects would be through the use of AIs with vaginal estrogen, however this association should be analyzed with caution because the place estrogen may interfere with the ability of the drug to suppress the production of endogenous estrogen [74].

\subsection{Ovarian Cancer}

In the world, were estimated 5.68 million new cases of ovarian cancer for the year 2014 [78]. It is rare the appearance of epithelial ovarian cancer before age 30 . The age group with the highest incidence is over 50 years [79].

The cancer of epithelial ovarian surface is quite common in women and is the result of hormonal changes related to ovulation [80]. After ovulation, induced by the action of gonadotropin, the follicular fluid is secreted estrogen in ovarian surface which determines the proliferation of epithelial cells from ovarian surface [81].

HRT users compared to non-users, have a $50 \%$ increased risk of developing the neoplasia. The rate of deaths from ovarian cancer in 100,000 women is $64.4 \%$ for users for ten years or more and $26.4 \%$ for non-users [82].

Regarding the duration of use of HRT, it was observed that the use of estrogen for more than ten years after menopause significantly increases the risk of death from ovarian cancer, persisting up to 29 years after discontinuation of use. Facing this, taking into account the risks of therapy, hormone replacement should only be recommended in short-term treatment (up to five years) for symptomatic control of vasomotor and genitourinary changes [82].

\section{Risk Group}

Because HRT has potential carcinogenic risk, several other factors must be analyzed. Family history of breast cancer, especially in first-degree relatives, is associated with a high risk in developing this disease [83, 84]. In regard to reproductive factors, it is observed that nulliparous and women who had their first pregnancy after age 30 are at higher risk for breast cancer and endometrial cancer than multiparous. These effects are related by no exposure to long periods of production of progesterone by the placenta. Also, early menarche and late menopause has been associated with increased risk of breast cancer [13, 84, 85].

Obesity is a major risk factor in the formation and progression of breast cancer and endometrium in postmenopausal women, whereas adipose tissue is a predisposing factor in the formation and development of tumor through hormonal and immunological pathways [37 86].

It has been shown that diabetes mellitus have a causal relationship with endometrial cancer and there are indications that it can be an independent risk factor [87]. Hypertension frames appear to be related comorbidities of age and the increased incidence of endometrial cancer [88].

Women with history of obesity in postmenopausal, ovarian cancer, high breast density, benign breast disease, tobacco exposure to ionizing radiation and organ chlorine pesticides are at high risk of developing the mammary tumors [89].

A sedentary lifestyle associated with poor diet is another risk group for the development of tumors. Results suggest that moderate physical activity reduces the levels of circulating estrogens and SHBG levels increase as a result of the reduction of body fat [90].

In this context, it can be concluded that HRT is not suitable for all menopausal women on, since the association between hormone therapy and those mentioned risk groups favors the development of neoplasms. The practice of moderate physical activity is recommended and a balanced diet to improve menopausal symptoms. So for women who are classified within the risk group, careful evaluations of the needs and risks of HRT should be performed.

\section{Conclusion}

In view of the mechanism of carcinogen administration of estrogens, it can be said that HRT increases the risk of breast, uterus and ovary cancer. However, the estrogenic action can be modulated when there progestogen drug administration and antiestrogenic and antiandrogenic action, then, the use of progestin should be evaluated for the benefit is observed. That is, the association between estrogens and progestins to estrogen action (tibolone and norethindrone acetate) and / or 
androgenic (medroxyprogesterone acetate, norethindrone acetate, desogestrel, levonorgestrel, norgestimate, norgestrel and tibolone) shows an increase in the incidence of neoplasms and should not be carried out.

Therefore, in menopausal women, it is advisable to trace gynecological cancer, before, during and afterwards of any therapeutic interventions and the decision of using and the choice of HRT on an individual basis, through a careful assessment of signs and symptoms and long-term risk.

\section{References}

[1] Lorenzi, D. R. S., L. Catan B.,Moreira, K., Ártico, G. R. (2009) Assistência a mulher climatérica: novos paradigmas. Rev Bras Enferm 62 (2), 287-93.

[2] Zahar S. E. V., Aldrighi, J. M. Neto A. M. P., Conde, D. M, Zahar., L. O., Russomano, F. (2005) Qualidade de vida em usuárias e não usuárias de terapia de reposição hormonal., Rev Assoc Med Bras 51 (3), 133-8

[3] North American Menopause Society . (2004) Treatment of menopause-associated vasomotor symptoms: position statement of The North American Menopause Society. Menopause 11 (1), 11-33.

[4] Pardini, D. (2007) Terapia hormonal da menopausa. Arq Bras Endocrinol Metab. 51 (6), 938-942.

[5] Tang, M.X., Jacobs D., Stern,,Y, . Marder, K., Schofiel, P., Gurland, B. Andrews, H., Mayeux, R. (1996) Effect of oestrogen during menopause on risk and age at onset of Alzheimer's disease. Lancet. 348 (9025), 429-32.

[6] Barros, I. M. L. (2010) Prevalência de aterosclerose de carótida e fatores associados em mulheres a partir do climatério. Tese. Universidade de São Paulo.

[7] Fernandes. E. C., Pinho-Neto, J. S. L., Gebara, O. C. E. (2008) I Diretriz Brasileira sobre Prevenção de Doenças Cardiovasculares em Mulheres Climatéricas e a Influência da Terapia de Reposição Hormonal (TRH) da Sociedade Brasileira de Cardiologia (SBC) e da Associação Brasileira do Climatério (SOBRAC). Arq Bras Cardiol 91(1 supl.1), 1-23.

[8] Lanzillotti, H. S., Lanzillotti, R. S., Trotte, A. P. R., Dias, A., Bornand, B., Costa, E. A. M. M. (2003) Osteoporose em mulheres na pós-menopausa, cálcio dietético e outros fatores de risco. Rev. Nutr., Campinas, 16 (2), 181-193.

[9] Leal, J. H. S., Cubero, D., Giglio, A. D. (2010) Hormonioterapia paliativa em câncer de mama: aspectos práticos e revisão da literaturaa. Rev Bras Clin Med; 8 (4), 338-43.

[10] Trindade, M. D. M., Tocci H. A. (2000) Câncer do endométrio uterino no climatério e os efeitos de hormonioterapia. Rev Enferm Unisa ; 1, 99-103.

[11] Toledo, M. C. S. (2012) Expressão dos receptores de estrógeno, progesterona, andrógeno e her2 no câncer epitelial de ovário. Dissertação. Universidade Estadual de Campinas 58f.

[12] Giacomini, D. R E., Mella, A. C. (2006) Reposição Hormonal: vantagens e desvantagens. Semina: Ciências Biológicas e Saúde 27 (1), 71-92.

[13] Araújo, N. L. C. J., Athanazio, D. A. (2007) Terapia de reposição hormonal e o câncer de endométrio. Cad. Saúde Pública 23 (11), 2613-2622.

[14] Grady, D., Gebretsadik, T., Kerlikowske, K., Ernster, V., Petitti, D. (1995) Hormone replacement therapy and endometrial cancer risk: a meta-analysis. Obstet Gynecol 85 (2), 304-13.

[15] Beral, V., Bull, D., Reeves, G. (2005) Million Women Study Collaborators. Endometrial cancer and hormone-replacement therapy in the Million Women Study. Lancet. 365 (9470), 1543-51.

[16] Shapiro, S., Kelly, J. P., Rosenberg, L., Kaufman, D. W., Helmrich, S. P., Rosenshein, N. B., Lewis, J. L. J., Knapp, R. C., Stolley, P. D., Schottenfeld, D. (1985) Risk of localized and widespread endometrial cancer in relation to recent and discontinued use of conjugated estrogens. N Engl J Med 313 (16), 969-72.

[17] http://www.moreirajr.com.br/revistas.asp?fase=r003\&id_mate ria $=4843$.

[18] National Health and Medical Research Council (2005) Hormone replacement therapy: Exploring the options for women. $45 \mathrm{f}$.

[19] Schierbeck L. L., et al. (2012) Effect of hormone replacement therapy on cardiovascular events in recently postmenopausal women: randomised trial. Br Med J 345, 1-11.

[20] http://www.mims.co.uk/Drugs/obstetrics-and-gynaecology/me nopausal-disorders/

[21] Brunton, L., Parker, K., Blumenthal, D., Buxton, I., Goodman \& Gilman - Manual de farmacologia e terapêutica. Ed. Artmed. 2010 .

[22] Vigo, F., Lubianca, J. N., Corleta, H. V. E. (2011) Progestógenos: farmacologia e uso clínico. Femina 39 (3), 127-137.

[23] Sitruk-Ware, R. (2004) New progestogens: a review of their effects in perimenopausal and postmenopausal women. Drugs Aging 21 (13), 865-83.

[24] Sitruk-Ware, R. (2006) New progestagagens for contraceptive use. Human Reproduction Update 12 (2), 169-178.

[25] Schindler, A. E., Campagnoli, C., Druckmann R., Huber, J., Pasqualini, J. R., Schweppe, K.W., Thijssen, J. H. (2008) Classification and pharmacology of progestins. Maturitas 61 (1-2), 171-80.

[26] Regenstrief Institute, Inc. and the Logical Observation Identifiers Names and Codes (LOINC) Committee. 2014.Avaiable in http://s.details.loinc.org/LOINC/10861-3.html?sections=Simple

[27] Fabjani, G., Tong, D., Czerwenka K.., Schuster, E., Speiser, P., Leodolter, S., et al. (2002) Human progesterone receptor gene polymorphism Progins and risk for breast cancer in Austrian women. Breast Cancer Res Treat 72 (2), 131-7.

[28] Hardman, J.G.; Limbird, L.E. Goodman \& Gilman As Bases Farmacológicas da Terapêutica. McGraw Hill, 11ª ed. 2006.

[29] Rang, H.P.; Dale, M.M.; Ritter, J.M.; Gardner, P. Farmacologia. Elsevier, $6^{\text {a }}$ ed. 2007.

[30] Cericatto, R. (2002) Expressão gênica do receptor estrogênico-a, blc-2 E c-myc em fibroadenomas e no tecido mamário normal circunjacente. Dissertação. Universidade Federal do Rio Grande do Sul. 
[31] C. E. Fernandes, J. Rennó Jr, E. A. P. Nahas, N. R. Melo, J. A. S Ferreiras, R. B. Machado, S. Peixoto. (2006) Síndrome de insuficiência androgênica - critérios diagnósticos terapêuticos. Rev. Psiq. Clín. 33 (3), 152-161.

[32] Management of osteoporosis in postmenopausal women: 2010 position statement of The North American Menopause Society. Menopause 17 (1), 25-54.

[33] Pardini, D. (2014) Terapia de reposição hormonal na menopausa. Arq Bras Endocrinol Metab 58 (2), 172-181.

[34] Fonseca, E. A. I. (2010) Influência da obesidade e da resistência à insulina sobre o desenvolvimento tumoral: Efeito da metformina. Dissertação. Universidade de São Paulo 45f.

[35] Stocks, T., Rapp, K., Bjørge, T., Manjer, J., Ulmer, H., Selmer, R., Lukanova, A., Johansen, D., Concin, H., Tretli, S., Hallmans, G., Jonsson, H., Stattin, P. (2009) Blood Glucose and Risk of Incident and Fatal Cancer in the Metabolic Syndrome and Cancer Project (Me-Can): Analysis of Six Prospective Cohorts. PLoS Medicine 6 (12), e1000201, 1-14.

[36] Hsing, A.W., Gao, Y-T., Chua, S., Deng, J., Stanczyk, F..Z. (2003) Insulin Resistance and Prostate Cancer Risk. Journal of the National Cancer Institute 95 (1), 67-71.

[37] Barp, C. G., Almeida, D. J., Freitas, G. B. L. (2014) Breast cancer and postmenopausal obesity: the risk factors in this relationship. Cancer Research Journal 2 (1), 9-14 11.

[38] Somboonporn, W., Davis, S. R. (2004) National Health and Medical Research Council. Testosterone effects on the breast: implications for testosterone therapy for women. Endocr Rev 25 (3), 374-88.

[39] Cauley, J. A., Lucas, F. L., Kuller, L. H., Pedra, K., Browner, W., Cummings, S. R. (1999) Elevated serum estradiol and testosterone concentrations are associated with a hight risk for breast cancer. Study of Osteoporotic Fractures Research Group. Ann Intern Med 130 (4 Pt 1), 270-7.

[40] Isotton, A. L., Wender, M. C. O., Czepielewski, M. A. (2008) Influências da reposição de estrógenos e progestágenos na ação do hormônio de crescimento em mulheres com hipopituitarismo. Arq Bras Endocrinol Metab 52 (5), 901-916.

[41] Walsh, B.W., Schiff, I., Rosner, B., Greenberg, L., Ravnikar, V., Sacks, F. M. (1991) Effects of postmenopausal estrogen replacement on the concentrations and metabolism of plasma lipoproteins. N Engl J Med. 325(17), 1196-204.

[42] Godsland, I. F., Gangar, K., Walton, C., Cust, M. P., Whitehead, M. I., Wynn, V., Stevenson, J. C. (1993) Insulin resistance, secretion, and elimination in postmenopausal women receiving oral or transdermal hormone replacement therapy. Metabolism 42 (7), 846-853.

[43] Serin, I. S., Özçelik B., Başbuğ, M., Aygen, E., Kula M., Erez, R. (2001) Long-term effects of continuous oral and transdermal estrogen replacement therapy on sex hormone binding globulin and free testosterone levels. Eur J Obstet Gynecol Reproductive 99 (2), 222-5.

[44] Bittner, J. J. (1948) The causes and control of mammary cancer in mice. Harvey Lect 42, 221-246.

[45] Meuten, D. J. Tumors in domestic animals. $4^{\mathrm{a}}$ Ed. 2002. Pg 788.

[46] Silva, A. E., Serakides, R., Cassali, G. D. (2004) Carcinogênese hormonal e neoplasias hormônio-dependentes. Ciência Rural 34 (2), 625-633.
[47] Henderson, B. E., Feigelson, H. S. (2000) Hormonal carcinogenesis. Carcinogenesis 21 (3), 427-433.

[48] Wigertz, A., Lönn , S., Mathiesen, T., Ahlbom, A., Salão, P., Feychting, M., Swedish Interphone Study Group. (2006) Risk of brain tumors associated with exposure to exogenous female sex hormones. Am J Epidemiol 164 (7), 629-36.

[49] Instituto Nacional do Câncer José Alencar Gomes da Silva. (2014). Câncer de mama. Available in http://www2.inca.gov.br/wps/wcm/connect/tiposdecancer/site/ home/mama

[50] Rosas, M. S. L., Silva, B. N. M., Pinto, R. G. M. P., Silva, B. V., Silva, R. A., Guerra, L. R., Sores G. C. M. T., Castro, H. C., Lione V. O. F. (2013) Incidência do Câncer no Brasil e o Potencial Uso dos Derivados de Isatinas na Cancerologia Experimental. Rev. Virtual Quim 5 (2), 243-265.

[51] Adorno, G. L. A. R. (2008) Angiogênese em carcinomas de mama: análise de expressão de fator de crescimento do endotélio vascular (VEGF) e suas correlações com outros fatores prognósticos. Dissertação. Universidade de Brasília $118 f$.

[52] Dickson, R. B., Stancel, G. M. (2000) Estrogen receptor-mediated processes in normal and cancer cells. J. Natl. Cancer Inst. Monogr 27, 135-145.

[53] Ettrich, B. G. (2011) Excesso de peso, adipocinas séricas e moléculas de adesão celular em mulheres com e sem câncer de mama. Dissertação. Universidade Federal do Rio Grande do Sul. 73f.

[54] Tabak, D. (2014) Obesidade e o câncer. Revista Onco, march/april, 22-25.

[55] Piovesan, A. C,. Soares, J. M. J., Mosquette, R., Simões, M. J., Simões, R. S., Baracat, E. C. (2005) Estudo morfológico e molecular da mama de ratas castradas tratadas com isoflavona ou estrogênios. Rev Bras Ginecol Obstet. 27 (4), 204-9.

[56] Instituto Nacional de Câncer José de Alencar Gomes da Silva (Inca). (2014) Estimativa 2014 - Incidência de Câncer no Brasil. Ministério da Saúde 124f.

[57] Garcia, M. G. M., Carvalho, M. G. F., Garcia, M. M. (1998) Análise dos fatores de risco em pacientes com adenocarcinoma endometrial. Reprodução \& Climatério 13 (4), 232-236.

[58] Ziel, H. K., Finkle, W. D. (1975) Increased risk of endometrial carcinoma among users of conjugated estrogens. N Engl J Med 293 (23), 1167-70.

[59] Smith, D. C., Prentice, R., Thompson, D. J., Herrmann, W. L. (1975) Association of exogenous estrogen and endometrial carcinoma. N Engl J Med 293, 1164-7.

[60] Grings, A. C., Kühne, J., Gomes, A. P., Jacobsen, T., Cascaes, A. C., Lara, G. M. (2009) Riscos e benefícios da terapia de reposição hormonal (TRH) em mulheres na menopausa. Rev. bras. anal. clin 41 (3), 231-234.

[61] Grady, D., Gebretsadik, T., Kerlikowske, K., Ernster, V., Petotto, D. (1995) Hormone replacement therapy and endometrial cancer risk: a meta-analysis. Obstet \& Gynecol 85 (2), 304-313.

[62] Wannmacher, L., Lubianca, J. N. (2004) Terapia de reposição hormonal na menopausa: evidências atuais. Uso racional de medicamentos: temas selecionados 1 (6), 1-6. 
[63] Rozenberg, S., Vandromme, J., Antoine, C. (2013) Postmenopausal hormone therapy: risks and benefits. Nat Ver Endocrinol 9, 216-227.

[64] Santos, L. O. M., Pessole, M. L., Ioshii, S. O. (2001) Efeito dos estrógenos conjugados e da Medroxiprogesterona sobre a mama. Revista brasileira de ginecologia e obstetrícia 23 (8), 23-35.

[65] Hulley, S., Grady, D., Bush, T., Furberg, C., Herrington, D., Riggs, B., Vittinghoff, E. (1998) Randomized trial of estrogen plus progestin for secondary prevention of coronary heart disease in postmenopausal women. Heart and estrogen/progestin replacement study (Hers) research group. Jama 280 (7), 605-613.

[66] Carvalheira, J. B. C., Saad. M. J. A. (2006) Doenças associadas à resistência à insulina/hiperinsulinemia, não incluídas na síndrome metabólica. Arq Bras Endocrinol Metab 50 (2), 360-367.

[67] Instituto Nacional do Câncer José Alencar Gomes da Silva. (2014) Síntese de Resultados e Comentários. Available in http://www.inca.gov.br/estimativa/2014/sintese-de-resultadoscomentarios.asp

[68] Hou, N., Hong, S., Wang, W., Olopade, O. I., Dignam, J. J., Huo, D. (2013) Hormone Replacement Therapy and Breast Cancer: Heterogeneous Risks by Race, Weight, and Breast Density. Journal of the National Cancer Institute 105(18), 1365-1372.

[69] Albuquerque, A. M., Tocci, H. A. (2000) A polêmica associação entre a terapia de reposição hormonal e o risco de câncer de mama no climatério. Rev Enferm Unisa 1, 90-4.

[70] Norman, A. W.. Litwack G. Hormones. 2 ${ }^{\mathrm{a}}$ Ed. 1997. Pg 558.

[71] Steinberg, K. K.., Thacker, S. B., Smith, S. J., Stroup, D. F., Zack, M. M., Flanders, W. D., Berkelman, R. L. (1991) A meta-analysis of the effect of estrogen replacement therapy on the risk of breast cancer. Jama 265, 1985-1989.

[72] Marinho, R. M.. Fernandes, C.E. Wehba. S., Baracat, E. C. (2001) Projeto diretrizes: atenção primária e terapia de reposição hormonal no climatério. Federação brasileira das Sociedades de Ginecologia e Obstetrícia Pg 1- 11.

[73] Lin, V. C-L., Jin, R., Tan, P-H., Aw, S-E., Woon, C-T., Bay, B-H. Progesterone Induces Cellular Differentiation in MDA-MB-231 Breast Cancer Cells Transfected with Progesterone Receptor Complementary DNA. American Journal of Pathology 162 (6), 1781- 1787.

[74] Kendall, A., Dowsett, M., Folkerd, E., Smith., I. (2006) Caution: Vaginal estradiol appears to be contraindicated in postmenopausal women on adjuvant aromatase inhibitors. Ann Oncol 17 (4),584-7.

[75] Dahir, M., Gustafson, D. T. (2014) Breast câncer, Aromatase Inhibitor Therapy, and Sexual Fuctioning: A pilot Study of the Effects of Vaginal Testosterone Therapy. Sex. Med 2 (1), 8-15.

[76] Moegele, M., Buchholz, S., Seitz, S., Ortmann, O. (2012) Vaginal estrogen therapy in postmenopausal breast cancer patients treated with aromatase inhibitors. Arch Gynecol Obstet; 285 (5), 1397-402.
[77] Antoine, C., Vandromme, J., Fastrez, M., Carly, B., Liebens, F., Rozenberg, S. (2008) A survey among breast cancer survivors: Treatment of the climacteric after breast cancer. Climacteric; 11 (4), 322-8.

[78] Instituto Nacional do Câncer José Alencar Gomes da Silva. (2014). Colorretal. Available in http://www2.inca.gov.br/wps/wcm/connect/tiposdecancer/site/ home/ovario

[79] Fernandes, L. R. A., Lippi, U. G. and Baracat, F. F. (2003) Índice de Risco de Malignidade para Tumores do Ovário, Incorporando Idade, Ultra-sonografia e o CA-125. RBGO 25 (5), 345-351.

[80] Fathalla, M. F. (1971) Incessant ovulation: a factor in ovarian neoplasia? The Lancet 298 (7716), 163.

[81] Roskelley, C. D., Bissel, M. J. (2002) The dominance of the microenvironment in breast and ovarian cancer. Cancer Biol 12 (2), 97-104.

[82] Rodriguez, C., et. al. (2001) Estrogen replacement therapy and ovarian cancer mortality in a large prospective study of US women. Jama 285 (11), 1460-1465.

[83] Aquino, L. C. M., Andrade, F. H. F. M., Góes, C. A. M., Ribeiro, E. M. (2005) Aspectos genéticos do câncer de mama hereditário. Rev Soc Bras de Câncer 8, 44-8.

[84] Leal, C. S., Santos, K. R.. R. A., Nunesmaia, H. G. S. (2002) Características epidemiológicas do câncer de mama no estado da Paraíba. Rev. Bras. De Matol 12 (2), 15-22.

[85] Pinho, V. F. S., Coutinho, E. S. F. (2007) Variáveis associadas ao câncer de mama em usuárias de unidades básicas de saúde. Cad. Saúde Pública 23 (5), 1061-1069.

[86] Anderson, A. S., Caswell, S. (2009) Obesity management--an opportunity for cancer prevention. Surgeon 7 (5), 282-285.

[87] Anderson, K. E., Anderson, E., Mink, P. J., Hong, C. P. Kushi, L. H., Sellers, T. A., Lazovich, D., Folsom, A. R. (2001) Diabetes and endometrial cancer in the Iowa women's health study. Cancer Epidemiol Biomarkers Prev 10 (6), 611-6.

[88] Safina, N. S., Urmancheeva, A. F., Tomilin, N. V., Krischen, O. V., Aksenov, N. L., Kazakov, V. I., Shramko, L. A. (2000) Parameters of lipid metabolism and polymorphism of apolipopretein a1 and angiotensin-converting enzyme genes in patients with endometrial carcinoma. Vopr Onkol 46 (1), 54-57.

[89] Gonçalves, L. L. C., Lima, A. V., Brito, E. S., Oliveira, M. M., Oliveira, L. A. R., Abud, A. C. F., Daltro, A. S. T., Barros, A. M M. S., Guimarães, U. V. (2010) Fatores de risco para câncer de mama em mulheres assistidas em ambulatório de oncologia. Rev. enferm 18 (3), 468-72.

[90] McTiernan, A., Tworoger, S. S., Ulrich, C. M., Yasui, Y., Irwin, M. L., Rajan, K. B., Sorensen, B., Rudolph, R. E., Bowen, D., Stanczyk, F. Z., Potter, J. D., Schwartz, R. S. S. (2004) Effect of exercise on serum estrogens in postmenopausal women: a 12-month randomized clinical trial. Cancer Res 64 (8), 2923-8. 